\title{
REVITALISASI ENTREPRENUERSHIP DI PONDOK PESANTREN
}

\author{
Halimatus Sakdiyah \\ (D osen D PK FE U niversitas Islam M adura, JI. Raya Panglegur km. 3,5 Pamekasan, \\ email: hsfeuim @ yahoo.co.id)
}

\begin{abstract}
A bstract:
Pondok Pesantren (Islamic boarding school) as the Islamic education institution is the asset of Indonesian education. It can survive in the middle of modernity to defense its existency and characteristics, it needs to develop the talent and interest of santri (Pondok Pesantren student). This development must be organized in systematic and well-programmed plan. As the agent of development, pondok pesantren becames a brigde and media to solve social economic problems in society. The research finds solutions that the role of pondok pesantren as the agent of development now become an institution that can expand a business field. An economic business that independent, well established that revitalizes entrepreneurship. The objective is to overcome the problem of poverty and inadvertently as the impact by the subordination of Muslim in economis and business field. Santri is the pioner to create a business condition that can hold up the development of Indonesian economic
\end{abstract}

\section{Key Words:}

revitalisasi, entreprenuership, pondok pesantren dan agent of devolepment

\section{Pendahuluan}

Pesantren merupakan salah satu jenis lembaga pendidikan Islâm tradisional di Indonesia yang dijadikan asset pendidikan genuine bangsa Indonesia yang mampu bertahan hidup ditengahtengah modernitas yang mempunyai sub kultur yang unik dan khas. 
Halimatus Sakdiyah

Salah satu keunikannya adalah indepensinya yang kuat sehingga menjadikan pesantren itu dapat menjadi salah satu contoh selfgoverning school atau autonomous school di mana kyai dengan leluasa mengekspresikan ide-idenya dalam menjalankan semua aktifitas pesantren dengan tujuan utama meningkatkan kemampuan santri. Untuk mengatasi adanya indepensi tersebut, perlu adanya sebuah kegiatan ekonomi untuk memenuhi kebutuhan finansial pesantren. Otonomi pesantren titik sentralnya terletak padan figur kyai, sehingga kemampuan kyailah yang akan menentukan merah hijaunya pesantren. Sementara disisi lain, para santri mempunyai ketundukan yang luar biasa terhadap kyai.

Kenyataan seperti tersebut menimbulkan permasalahan ditengah dunia yang terus berubah. Pesantren tradisional harus bekerja maksimal untuk meningkatkan kapasitas santrinya dalam menghadapi isu global masyarakat Indonesia dengan memberikan bekal kepada para santri untuk lebih maju.

Sudah tidak masanya lagi institusi sekelas pondok pesantren hanya berkutat dengan masalah pendidikan dan pengajaran dengan metode pendidikan tradisional, karena hal ini tentunya akan mereduksi perannya sebagai agent of development. Sebaliknya lembaga pendidikan tertua di Indonesia ini haruslah dapat merambah dunia bisnis. Hal ini dikarenakan lembaga ini memiliki posisi yang strategis dalam mengemban peran-peran pengembangan pendidikan maupun sosial ekonomi bagi masyarakat sekitar. Pondok pesantren telah mengalami berbagai pengembangan internal yang memungkinkan besarnya peluang pondok pesantren untuk berperan sebagai agent of devel opment dalam rangka menjembatani dan memecahkan persoalan sosial ekonomi masyarakat.

Pondok pesantren dipandang memilki potensi besar dalam pembangunan dengan tenaga-tenaga usia muda yang dimiliki merupakan sebuah aset Sumber Daya Manusia yang potensial yang tidak hanya dalam menyebarkan ilmu agamanya namun juga dalam menyebarkan informasi dan inovasi-inovasi. Selama ini kegiatan di pondok pesantren lebih banyak diarahkan kepada kegiatan keagamaan, sedangkan kegiatan keterampilan dibidang usaha dirasakan masih perlu untuk lebih ditingkatkan. 
Terjadinya kegagalan pada model pembangunan pada masa Ialu, menyadarkan akan perlunya reorientasi baru dalam pembangunan, yaitu pendekatan pembangunan yag memperhatikan lingkungan dan pembangunan yang berwajah manusiawi sebagai faktor kunci yang memainkan peran penting dalam segala segi. Proses pembangunan hendaknya sebagai suatu proses yang populis, konsentrasi pembangunan lebih pada ekonomi kerakyatan, dengan mengedepankan fasilitas pembangunan pada usaha rakyat kecil. Bertolak dari model pembangunan yang humanis tersebut maka dibutuhkan program-program pembangunan yang memberikan prioritas pada upaya memberdayakan masyarakat. Dalam konteks Good governance ada tiga pilar yang harus menopang jalannya proses pembangunan yaitu masyarakat sipil, pemerintah dan swasta. Oleh karena itu Sumber Daya Manusia atau masyarakat menjadi pilar utama yang harus diberdayakan sejak awal.

Kondisi ekonomi Umat Islâm yang semakin terpuruk, dengan melihat disatu sisi Sumber Daya Manusia yang potensial yang dimiliki oleh pondok pesantren maka sangatlah perlu adanya revitalisasi entreprenuership bagi umat Islâm. Fenomena kemerosotan umat Islâm di bidang ekonomi merupakan sebuah problem kemiskinan dan keterbelakangan akibat berada pada kondisi yang termarginalkan dalam ekonomi dan bisnis. Perlu adanya pembuktian untuk menangkis adanya sebuah fenomena tersebut dengan menggarisbawahi bahwa pondok pesantren sebagai institusi pendidikan bernuansa Islâm dapat mengembangkan potensi wirausaha yang dimiliki. Dengan pengembangan Sumber Daya Manusia inilah nantinya akan memupuk rasa keberanian dalam menanggung resiko, memiliki kreativitas, memiliki keterampilan dan mampu mengembangkannya menjadi suatu lahan dalam menghimpun modal bagi pengembangan pondok pesantren itu sendiri dan bagi para santrinya.

\section{Pondok Pesantren sebagai Agent of D evolepment}

Arus globalisasi telah banyak merubah budaya bangsa Indonesia dalam hitungan dasawarsa. Globalisasi sendiri dibutuhkan karena dipercaya bisa mempercepat pertumbuhan ekonomi 
Halimatus Sakdiyah

sedangkan disisi lain dikhawatirkan bisa melunturkan nilai-nilai luhur tradisional sebuah bangsa.

Penanaman nilai- nilai agama yang memiliki kebenaran mutlak dan berorientasi pada kehidupan ukhrawi didalam lembaga pendidikan pesantren bertujuan untuk mendidik para santri agar memiki aqidah yang kuat, syariat yang matang dan ilmu pengetahuan yang mumpuni. Penanaman nilai moral juga mendapat tempat sigifikan dalam setiap pesantren. Hal ini disebabkan karena para kyai adalah pewaris para Nabi. Nabi tidak mewariskan apapun kecuali ilmu pengetahuan dan akhlaq yang mulia. Dari pembelajaran tersebut menstimulasi para santri membiasakan diri menjadi santri yang disiplin dalam bersikap, disiplin dalam ibadah dan disiplin dalam amaliyah yang sangat membutuhkan proses panjang dan perjuangan yang gigih dari santri itu sendiri. ${ }^{1}$

Pondok pesantren adalah lembaga pendidikan Islâm untuk mempelajari, memahami, mendalami, menghayati, dan mengamalkan ajaran Islâm dengan menekankan pentingnya moral keagamaan sebagai pedoman prilaku sehari-hari. Perkembangan selanjutnya, pondok pesantren tidak hanya berperan sebagai lembaga pendidikan keagamaan, dan kemasyarakatan saja tetapi juga berperan sebagai pengembangan masyarakat (commonity development), perubahan sosial (agent of change), dan pembebasan (liberation) pada masyarakat dari ketertindasan, keburukan moral, politik dan kemiskinan.2

Pemerintah, melalui Direktorat Jendral Industri Kecil dan Menengah, Departemen Perindustrian, dan kementrian Koperasi dan Usaha Kecil Menengah telah berkomitmen untuk mengembangkan dan memberdayakan program ekonomi kerakyatan di Pesantren. Hingga tahun 2007 Ditjen Usaha Kecil Menengah Departemen Perindustrian telah berhasil membina lebih dari 700 pondok pesantren yang tersebar di 26 provinsi. Pembinaan yang dilakukan meliputi antara lain program bantuan teknis, pendampingan tenaga ahli, pelatihan keterampilan, hingga bantuan peralatan produksi.

1 Kholik, “Dunia Intelektualitas dan Religius” http: / / pp.salaf.go.id . diakses tanggal 19 January 2009

2 "Penerapan Fungsi-fungsi Manajemen dalam Mengembangkan Dana", http:/ / salafiyah.org. diakses tanggal 12 A pril 2009 
Tujuan dari pembinaan itu antara lain untuk menyiapkan para santri menjadi wirausaha baru, disamping juga untuk menyiapkan sumber pendapatan pesantren, lalu memanfaatkan potensi dan asset pesantren kearah usaha produktif. Serta untuk meningkatkan kualitas dan profesionalisme di kalangan pesantren. Pondok pesantren sangat memiliki potensi kewirausahaan yang besar untuk didayagunakan sebagai suatu kekuatan yang mampu mengatasi problem kemiskinan dan pengangguran dalam rangka mewujudkan pesantren sebagai agent of development dan soko guru ekonomi nasional yang baru. ${ }^{3}$

\section{Pengetahuan M asyarakat tentang Entreprenuership}

Berusaha merupakan salah satu alasan dalam rangka melanjutkan keberlangsungan hidup. $\mathrm{Hal}$ ini memotivasi lahirnya kreativitas secara personal sebagai santri ataupun kolektif dalam sebuah lembaga pondok pesantren. Kreativitas yang dimaksud adalah melakukan pekerjaan yang sesuai dengan kemampuan dirinya, sehingga melaksanakan pekerjaan tersebut dirancang, dikelola dan dikendalikan dengan baik. Wirausaha adalah seseorang yang bebas dan memiliki kemampuan untuk hidup mandiri dalam menjalankan kegiatan usahanya atau dunia bisnisnya.

Pengertian kewirausahaan adalah kemampuan kreatif dan inovatif yang dijadikan dasar, kiat dan sumber daya untuk mencari peluang menuju sukses. Inti dari kewirausahaan adalah kemampuan untuk menciptakan sesuatu yang baru dan berbeda (create new and different) melalui berfikir kreatif dan inovatif dimana kewirausahaan merupakan kemampuan dalam menciptakan nilai tambah di pasar melalui proses pengelolaan sumber daya dengan cara-cara baru dan berbeda melalui: (1) Pengembangan tekhnologi baru; (2) penemuan pengetahuan ilmiah baru; (3) perbaikan produk barang atau jasa; dan (4) penemuan cara-cara baru untuk menghasilkan barang lebih banyak dengan sumber daya lebih efisien.

Kreativitas adalah kemampuan untuk mengembangkan ideide baru dan cara-cara baru dalam pemecahan masalah dalam

3 D. Zumar, Etos W irau saha Pesan tren, (Jakarta: Small-M edium Industry, 2008) 
Halimatus Sakdiyah

menemukan peluang. Sedangkan inovasi adalah kemampuan untuk menerapkannya. ${ }^{4}$

Bangsa Indonesia mempunyai potensi dan bakat terpendam untuk dapat maju. Namun persoalannya adalah bagaimana bakat dan potensi yang dipunyai itu dapat tereksploitasi. Kewirausahaan dipandang sebagai fungsi yang mencakup eksploitasi peluangpeluang yang muncul di pasar. Eksploitasi tersebut sebagian besar berhubungan dengan pengarahan dan atau kombinasi input yang produktif. Seorang wirausahawan selalu diharuskan menghadapi resiko atau peluang yang muncul, serta sering dikaitkan dengan tindakan kreatif dan inovatif. Bangsa Indonesia mempunyai potensi namun belum ada pihak-pihak yang mempunyai otoritas yang mampu menyerap potensi tersebut dan menuangkannya ke dalam sebuah konsep terpadu guna meningkatkan taraf hidup bangsa. Potensi terpendam yang dimaksud adalah semangat dan bakat kewirausahaan. Bangsa kita, yang terpresentasikan oleh lapisan masyarakat kelas bawah, adalah bangsa yang memiliki daya juang, kreativitas serta semangat kewirausahaan tinggi. Ini merupakan modal intangible yang sungguh-sungguh potensial.

Seorang wirausahawan menjalankan peranan manajerial dalam kegiatannya, dalam sebuah proses penciptaan sesuatu yang berbeda nilainya dengan menggunakan usaha dan waktu yang diperlukan, memikul resiko finansial, psikologi dan sosial yang menyertainya, serta menerima balas jasa dan akan mendapatkan kepuasan pribadi.

Perkembangan pribadi dan tingkah laku manusia dipengaruhi oleh faktor bawaan dan pengaruh dari lingkungannya. Lingkungan memberikan warna terhadap perkembangan jiwa individu. Tumbuh dan berkembangnya jiwa wirausaha ditentukan oleh faktor bawaan dan pengaruh lingkungan. Faktor-faktor yang mempengaruhi jiwa wirausaha antara lain: Pertama, intelegensia. Kemampuan individu secara sadar untuk menyesuaikan pemikirannya terhadap tuntutan baru, yaitu penyesuaian mental terhadap masalah dan keadaan baru. Intelegensia terkait dengan pemecahan masalah perencanaan,

4 Suryana, Kewirausahaan; Pedoman Praktis, Kiat dan Proses M enuju Sukses (Jakarta: Salemba Empat, 2003) 
pengejaran prestasi yang sangat berarti untuk membuka jiwa wirausaha. Kedua, latar belakang budaya. Manusia tidak lepas dari lingkungan sekitar, sehingga mereka secara tidak langsung dibatasi oleh normal/ nilai - nilai budaya setempat dimana kita berasal. Sedangkan kebudayaan adalah cara manusia membentuk dan menentukan prilaku manusia. Ketiga, jenis kelamin. Pria dilambangkan agresif, independensi, ambius, sedangkan wanita dilambangkan sensitif, kooperatif dan intitutif. Keempat, tingkat pendidikan. Kelima, usia. Keenam, pola asuh keluarga.

Kewirausahaan (entreprenuership) merujuk kepada kepribadian tertentu, yaitu pribadi yang mampu berdiri diatas kemampuan sendiri, mengambil keputusan untuk diri sendiri serta mampu menerapkan tujuan yang ingin dicapai atas perencanaan sendiri. Setiap usaha yang dikerjakan bahkan oleh mereka yang meraih kesuksesan selalu dimulai dengan adanya semangat kewirausahaan (entreprenuership spirit). 5

Keberhasilan seorang wirausaha bergantung pada kesediaannya bertanggung jawab atas pekerjaan yang dilakukan. Kegagalan dan keberhasilan dalam usaha harus diterima sebagai pengalaman. Keberhasilan adalah buah dari segala usaha yang tidak kenal Ielah.

\section{Entreprenuership menurut Pandangan Islâm}

Agama Islâm memang tidak memberikan pengertian secara eksplisit terkait dengan konsep tentang kewirausahaan, namun diantara keduanya mempunyai kaitan yang cukup erat, memiliki ruh atau jiwa yang sangat dekat meskipun bahasa teknisnya yang berbeda. Secara historis, umat Islâm di Indonesia memilki naluri berbisnis yang luar biasa. Pada masa sebelum penjajahan dapat diketahui bahwa para santri memiliki semangat dan gairah yang besar untuk terjun dalam dunia bisnis, sebagaimana yang diajarkan para pedagang muslim penyebar agama Islâm. Hal ini mudah dipahami karena Islâm memiliki tradisi bisnis yang tinggi dan 
Halimatus Sakdiyah

menempatkan pedagang yang jujur pada posisi terhormat bersama Nabi, Syuhada, dan orang-orang solih.

Dalam Islâm menggunakan perumpamaan tentang pengertian kewirausahaan seperti kerja keras, kemandirian (biyadihi), dan tidak cengeng. Setidaknya terdapat beberapa ayat al-Qur'ân maupun Hadist yang dapat menjadi rujukan pesan tentang semangat kerja keras dan kemandirian ini, seperti, "Amal yang baik adalah pekerjaan yang dilakukan dengan cucuran keringatnya sendiri" (HR. Abu Dawud). Nabi mendorong umatnya untuk bekerja keras supaya memiliki kekayaan, sehingga dapat memberikan sesuatu pada orang Iain, atuzzakah. (Q.S al-Nisâ': 77). Bekerja keras merupakan esensi dari kewirausahaan dimana prinsip dari kerja keras merupakan sebuah langkah nyata yang dapat menghasilkan kesuksesan (rejeki), tetapi harus melalui proses yang penuh dengan tantangan (resiko). Orang yang berani melewati resiko akan memperoleh peluang rizki yang besar. Dalam sejarahnya Nabi Muhammad SAW, istrinya dan sebagian besar para sahabatnya merupakan para pedagang dan entreprenuer mancanegara yang handal. Beliau adalah praktisi ekonomi dan sosok tauladan bagi umatnya. Oleh karena itu, dapat dikatakan bahwa mental atau jiwa entreprenuership inhern dengan jiwa umat Islâm itu sendiri. ${ }^{6}$

Bagi umat Islâm berdagang lebih kepada bentuk ibadah kepada Allâh SWT. Karena apapun yang kita lakukan harus memiliki niat untuk beribadah agar mendapat berkah. Berdagang dengan niat ini akan mempermudah jalan kita mendapatkan rizki. Berwirausaha memberi peluang kepada orang lain untuk berbuat baik dengan cara memberikan pelayanan yang cepat, membantu memberikan kemudahan dalam transaksi jual beli. Dalam QS. al-Baqarah: 275 dijelaskan bahwa Allâh SWT telah menghalalkan kegiatan jual beli dan mengharamkan riba. Kegiatan riba ini sangat merugikan karena membuat kegiatan perdagangan tidak berkembang. Ha ini disebabkan karena uang dan modal hanya berputar pada satu pihak saja yang akhirnya dapat mengeksploitasi masyarakat yang terdesak oleh kebutuhan hidup.

6 Subur, "M ental Kewirausahaan", http:/ / insanku.files.wordpress.com. Diakses tanggal 4 Maret 2009. 
Untuk mencapai sukses dalam karir maka harus dimulai dengan kerja keras. Kemudian diikuti dengan mencapai tujuan dengan orang lain, penampilan yang baik, keyakinan diri, membuat keputusan, pendidikan, dorongan ambisi, dan pintar berkomunikasi. Allâh memerintahkan umatnya untuk bertawakkal dan bekerja keras untuk dapat mengubah nasib. Jadi, kesimpulannya adalah bahwa ininsiatif, motivasi, kreatif yang dapat menumbuhkan jiwa entreprenuer dalam memperbaiki hidup. Selain itu dianjurkan untuk tetap berdo'a dan memohon perlindungan kepada Allâh SWT dalam setiap kita berusaha.

Gambaran diatas setidaknya menjadi bukti nyata bahwa etos bisnis yang dimiliki oleh umat Islâm sangatlah tinggi, atau dengan kata lain Islâm dan berdagang ibarat dua sisi dari satu keping mata uang. Benarlah apa yang disabdakan oleh Nabi Muhammad SAW," $\mathrm{H}$ endaklah kamu berdagang karena didalamnya terdapat sembilan puluh persen pintu rizki" (HR.Ahmad). Tantangan yang dihadapi saat ini adalah bagaimana cara membangunkan umat Islâm dari keterpurukan etos kerja yang mengalami penurunan dan degradasi. Etos kerja umat Islâm dapat ditingkatkan dengan menanamkan jiwa kewirausahaan melalui kebangkitan ekonomi syariah yang dilaksanakan oleh pesantren.

\section{Menciptakan Paradigma Entreprenuership bagi Masyarakat Pesantren}

Pendidikan kewirausahaan (entreprenuership) di Indonesia masih kurang memperoleh perhatian yang cukup memadai, baik oleh dunia pendidikan, masyarakat, maupun pemerintah. Banyak praktisi pendidikan yang kurang memperhatikan aspek-aspek penumbuhan mental, sikap, dan perilaku kewirausahaan peserta didik, baik di lembaga pondok pesantren, sekolah kejuruan, perguruan tinggi maupun profesional sekalipun. Orientasi mereka, pada umumnya hanya pada upaya-upaya menyiapkan tenaga kerja yang siap pakai. Sementara itu dalam masyarakat sendiri telah berkembang lama kultur feodal yang diwariskan oleh jaman penjajahan Belanda. Sebagian besar anggota masyarakat memiliki persepsi dan harapan bahwa output dari lembaga pendidikan dapat menjadi pekerja dalam 
Halimatus Sakdiyah

hal ini menjadi pegawai ataupun karyawan yang memiliki status sosial yang cukup tinggi. Bertolak dari pemahaman tersebut tentunya sangat penting untuk meningkatkan output yang dihasilkan dari lembaga pendidikan pondok pesantren melalui metode pengintegrasian sistem pendidikan modern yang salah satunya adalah program pengembangan budaya kewirausahaan (entreprenuership).

Kewirausahaan di sini bukan sekedar membuka usaha sendiri, namun lebih dari itu kewirausahaan dimaknai sebagai momentum untuk mengubah mentalis, pola pikir dan perubahan sosial budaya dengan kemampuan melihat dan menilai kesempatan-kesempatan (peluang) bisnis serta kemampuan mengoptimalisasikan sumberdaya dan mengambil tindakan serta bermotivasi tinggi dalam mengambil resiko dalam rangka mensukseskan bisnisnya.

Peran wirausaha adalah memperbaharui dengan keberanian melihat dan mengubah apa yang sudah dianggap mapan, rutin, dan memuaskan. Peran lain dari wirausaha adalah sebagai inovator yang menghadirkan hal-hal baru di masyarakat. Di samping itu juga mengambil dan memperhitungkan resiko yag berperan untuk mencari peluang dan memanfaatkannya. Serta menciptakan organisasi baru. Selanjutnya hasil karya itu sendiri adalah untuk menghasilkan sumber daya baru yang sejahtera dan juga dapat meningkatkan kemampuan sumber daya yang ada untuk menciptakan kesejahteraan bersama. Kewirausahaan dapat dikatakan berjalan dengan baik, apabila pelaksananya memiliki karakteristik pribadi wirausaha.

Kemampuan wirausaha menjadi salah satu hal yang menjadi program kegiatan pondok pesantren bertujuan tidak hanya mampu menerapkan ilmu yang diperoleh di pesantren, tetapi juga mampu menciptakan lapangan pekerjaan bukan hanya untuk mencari lapangan pekerjaan yang semakin terbatas karena persaingan lifeskill.

\section{Revitalisasi Entreprenuership bagi Pondok Pesantren}

Dalam kurun satu abad terakhir, dibanyak percaturan politik, ekonomi dan budaya kaum muslim dikatagorikan sangatlah jauh tertinggal dibandingkan dengan kelompok masyarakat lain di dunia 
ini. Sebagai masyarakat yang menganut agama Islâm tentunya hal ini sangat menggelitik dan menyakitkan apabila kita dituduh sebagai orang Islâm yang malas dan miskin.

Dari 56 negara yang mayoritas muslim, masing-masing memiliki rata-rata 10 Universitas, yang berartitotal lebih kurang 600 universitas, untuk 1,4 milyar penduduknya. Kita bandingkan dengan negara India yang memiliki 8.407 universitas. Sementara Amerika Serikat mempunyai 5.758 universitas. Dari 1,4 milyar warga Nobel. Untuk mereka yang layak disebut ilmuwanpun, kaum muslim hanya punya kurang lebih 300.000 orang. Artinya, kaum muslim hanya memiliki 230 ilmuwan persatu juta warganya. Sementara Amerika memiliki 1,1 juta ilmuwan (4.099 persatu juta) dan Jepang punya 70.000 (5.095 persatu juta). Untuk lingkup lebih sempit, yakni di negara Indonesia sendiri, keadaannya tidak jauh berbeda. Sampai tahun 2000-an, kaum muslim Indonesia termasuk dalam kelompok marginal. Terutama dalam percaturan ekonomi dan bisnis nasional. 7

Islâm adalah agama yang sangat mementingkan kerja atau amal. A gama Islâm tidak menghendaki bahkan membenci orang yang bermalas-malasan. Bahkan untuk menunjukkan betapa pentingnya bekerja dan beramal itu, dalam al-Qur'ân seringkali menggabungkan kata iman dengan kata amal. Secara tegas memberikan sebuah pemahaman yang mendorong manusia khususnya umat Islâm untuk mengembangkan etos kerja yang bersumber pada firman Allâh di dalam AI-Qur'an Surat al-Ra'd ayat 11, "Sesungguhnya A llâh SWT tidak akan mengubah keadaan sesuatu kaum sehingga mereka merubah keadaan yang ada pada diri mereka sendiri". Hal ini dapat digarisbawahi bahwa keadaan tersebut dapat diubah denngan adanya motivasi, tekad dan usaha dari mereka sendiri. Namun secara realita dalam masyarakat kita arti etos kerja ini belum sepenuhnya membudaya. Artinya budaya kerja dari sebagian masyarakat belum sesuai dengan kehidupan modern saat ini. Tentunya ini tidak bisa dihubungkan dengan budaya Islâm, karena budaya Islâm menghendaki orang bekerja keras. Islâm mengajarkan pemeluknya agar berwirausaha.

7 “Revitalisasi Jiwa Kewirausahaan”, http:// islami.com. Diakses tanggal 19 Nopember 2008. 
Halimatus Sakdiyah

Dalam upaya membangun kembali semangat dan jiwa kewirausahaan umat Islâm Indonesia, ada tiga dasar pemikiran mengapa rekontruksi entreprenuership umat Islâm menjadi penting antara lain: Pertama, Umat Islâm sejak kelahirannya, memiliki jiwa dan etos kewirausahaan yang tinggi. Nabi Muhammad dan sebagian besar sahabat-sahabatnya adalah para pedagang dan entreprenuer mancanegara. Proses penyebaran Islâm ke berbagai penjuru dunia sampai abad $13 \mathrm{M}$, dilakukan oleh para pedagang muslim. Masuknya Islâm ke negara Indonesia dan penyebarannya di Asia Tenggara, juga dibawa oleh para pedagang tersebut.A jaran Islâm sangat mendorong entreprenuership bagi umatnya, karena itu bagi orang muslim jiwa kewirausahaan tersebut seharusnya sudah menjadi bagian dari hidupnya. Islâm mengajarkan kepada pemeluknya agar bekerja dan beramal, sesuai Firman Allâh: Apabila kamu telah melaksanakan solat, maka bertebaranlah kamu dimuka bumi dan carilah rezeki Allâh dan ingatlah Allâh sebanyak-banyaknya agar kamu beruntung. (Surat At Taubah: Ayat 105).

Kedua, Kondisi ekonomi umat Islâm di negara Indonesia ini dalam jangka waktu yang cukup lama berada dalam keterpuukan, maka perlu adanya revitalisasi entreprenuership bagi umat Islâm. Kita perlu prihatin melihat kondisi ini tentang fenomena kemerosotan umat Islâm di Bidang ekonomi.

Ketiga, Kehadiran lembaga-lembaga perbankan dan keuangan syariah dewasa ini hendaknya diimbangi dengan tumbuhnya para entreprenuer muslim. Perkembangan ekonomi syarî'ah dalam bentuk lembaga perbankan dan keuangan syarî'ah yang saat pesat saat ini, seharusnya dibarengi dengan peningkatan etos entreprenuership umat Islâm. Dengan tumbuhnya etos entreprenuer yang tinggi khususnya bagi generasi umat akan berdampak positif terhadap kemajuan dan kebangkitan ekonomi umat sebagaimana yang terjadi dimasa silam sekaligus berdampak positif bagi perbankan dan lembaga keuangan itu sendiri. Karena itu, para pengusaha muslim hendaknya dapat memanfaatkan lembaga keuangan dan perbankan tersebut dalam mengembangkan usahanya. ${ }^{8}$

8 “Pengelolaan Kewirausahaan”, http:/ / www.scribd.com/ doc/ 4933265/ 
Semangat entreprenuership tersebut diatas harus dianggap sebagai salah satu unsur terpenting dalam gerakan ekonomi syarî'ah yang sedang berlangsung. Lembaga pendidikan Islâm dalam hal ini pondok pesantren harus menjadikan entreprenuership sebagai salah satu materi dalam kurikulum pendidikan, baik pendidikan menengah maupun pendidikan Tinggi. Demikian ormas Islâm ataupun para ulama harus turut memberikan motivasi para anggotanya untuk mengembangkan entreprenuership untuk merevitalisasi etos entreprenuership yang sekian lama kurang dianggap penting dalam konstruksi peradaban Islâm.

\section{Peran Revitalisasi sebagai Agent of Development bagi Pondok Pesantren}

Upaya membangun kembali semangat dan jiwa kewirausahaan umat Islâm di Indonesia, merupakan sebuah keniscayaan yang tidak dapat ditawar lagi. Kini saatnya kita mengembangkan dan membangun pengusaha-pengusaha yang memperhatikan pemerataan ekonomi yang dicita-citakan oleh umat Islâm yang tangguh dalam jumlah yang cukup besar. Tujuannya untuk mewujudkan negara Indonesia dengan membangun landasan yang kokoh, yakni dengan memperbanyak pilar para pengusaha pribumi yang menyangga bangunan ekonomi bangsa.Ditangan para santrilah hal ini dapat diwujudkan karena para santri adalah pioner kewirausahaan di kalangan pribumi sehingga mereka selalu diidentikkan dengan kelas pedagang (orang pasar). Etos kewirausahaan ada pada para kaum santri yang pada umumnya memiliki etos kewirausahaan dan etos kerja yang lebih tinggi dibandingkan dengan kaum agama lainnya. Etos kewirausahaan ada pada para kaum santri yang pada umumnya memiliki etos kewirausahaan dan etos kerja yang lebih tinggi dibandingkan dengan kaum agama lainnya.

Di Jawa, para santri reformis mempunyai profesi sebagai pedagang atau wirausahawan yang mempunyai etos entreprenuership yang tinggi. Prediksi dimasa yang akan datang para santri akan tampil sebagai elite pengusaha pribumi di negeri ini.9 Hal ini

${ }_{9}$ Clifford Geert, Pedler and Princes, (N ew Jersey: Prentice Hall, 1995). 
Halimatus Sakdiyah

dikarenakan munculnya gerakan syarî'ah yang turut mendorong tumbuhnya etos entreprenuership itu direvitalisasi. Dengan perkembangan ekonomi syarî'ah, muncul horizon baru untuk merekontruksi etos entreprenuership tersebut.

Pondok pesantren sebagai agent of devolepment merupakan lembaga pendidikan yang merupakan aset bangsa yang cukup mengakar dalam kehidupan masyarakat. Sebagai lembaga dakwah, pesantren mempunyai perananan yang besar dalam pembinaan umat yang telah mencetak kader-kader ulama, mencerdaskan masyarakat serta mampu menanamkan semangat kewiraswastaan dalam merivitalisaasi entreprenuership, mampu memberikan semangat berdikari dan memilki potensi untuk menjadi pelopor pembangunan masyarakat di lingkungan pondok pesantren. Sehingga cakupan kegiatan pondok pesantren semakin luas dan mendalam. Kegiatan tidak lagi terbatas pada pendidikan agama, dakwah, pembinaan umat dan kegiatan sosial lainnya, tetapi juga telah merambah pada kegiatan ekonomi.

Dalam revitalisasi entreprenuership pada pondok poesantren sebagai agent of devolepment tentunya disesuaikan dengan misi utama sebuah pondok pesantren, yakni diantaranya membangkitkan kesadaran umat Islâm akan pentingnya generasi muda yang berkualitas tinggi dan berjiwa Islâmi, menggelorakan syiar Islâm serta mensukseskan program belajar mengajar dengan tujuan pondok pesantren sebagai lembaga pendidikan ke Islâman mampu terus mempertahankan esistensinya dalam menjawab tuntutan kebutuhan masyarakat sesuai perubahan zaman. Pondok pesantren sebagai lembaga pendidikan yang melakukan transfer ilmu-ilmu agama dan nilai-nilai Islâm, sebagai kontrol sosial kemasyarakatan serta sebagai lembaga keagamaan yang melakukan pengembangan masyarakat sehingga pondok pesantren akan terus berperan sebagai salah satu agen perubahan didalam mendidik generasi masa depoan Indonesia untuk menghadapi arus globalisasi. Selaras dengan pembinaan yang dilakukan oleh lembaga pondok pesantren untuk keberhasilan para santrinya tentunya para santri dibekali keterampilan dengan tujuan membentuk soft skill para santri. Soft skill merupakan tingkah laku yang dapat mengembangkan dan memaksimumkan kinerja santri misalnya dengan memberikan pelatihan - pelatihan kewirausahaan di 
lingkungan pondok pesantren sehingga dapat tercermin dalam prilaku yang memiliki kepribadian, sikap, dan prilaku yang dapat diterima dalam kehidupan masyarakat dengan kemampuan kewirausahaan yang handal. Dengan dibekali pengetahuan kewirausahaan yang memadai dan disertai prakteknya, maka para santri akan mempunyai kemauan dan kemampuan yang memadai, sehingga tidak akan kebingungan ketika harus memasuki pasar kerja.

\section{Penutup}

Kewirausahaan sangat penting dalam menentukan kemajuan perekonomian suatu negara. Sedangkan Pondok pesantren sebagai agent of devolepment haruslah dapat mengembangkan potensi wirausaha yang dimiliki untuk mengatasi konstalasi perekonomian yang serba tak menentu. Dilingkungan Pesantren sudah tertanam nilai-nilai wirausaha dengan mengikuti keteladanan Nabi Muhammad SAW yang mampu mengajak umatnya untuk hidup mandiri dengan cara berwirausaha. Islâm bukan hanya berbicara tebntang entreprenuership (meskipun dengan istilah kerja mandiri dan kerja keras), tetapi langsung mempraktikkannya dalam kehidupan nyata. Sudah saatnya umat Islâm bangkit dari kesulitan ekonomi dalam menghadapi problem kemiskinan dan keterbelakangan akibat termarjinalkan dalam dunia ekonomi dan bisnis dengan membangun jiwa entreprenuership yang tangguh. Banyaknya entreprenuer merupakan indikator suatu negara maju dan makmur, jika entreprenuer banyak maka akan mendorong kemajuan bangsa dengan indikator: rendahnya angka pengangguran dan tingginya devisa terutama dari barang dan jasa dan eksport yang dihasilkan.

\section{D aftar Pustaka}

Alma Bukhari, Kewirausahaan (Bandung, Alfabeta, 2003)

Clifford Geertz, P edler and Princes, (N ew Jersey: Prentice Hall, 1995)

D. Zumar, Etos W irausaha Pesantren, (Jakarta: Small-M edium Industry, 2008) 
Halimatus Sakdiyah

Kholik, "Dunia Intelektualitas dan Religius" http: // pp.salaf.go.id . diakses tanggal 19 January 2009

Meredith, G. Kewirausahaan: M anajemen U saha Kecil. Jakarta: Salemba Empat, 2002.

Subur, "M ental Kewirausahaan", http:/ / insanku.files.wordpress.com. Diakses tanggal 4 Maret 2009.

Suryana, Kewirausahaan; Pedoman Praktis, Kiat dan Proses M enuju Sukses (Jakarta: Salemba Empat, 2003)

"Pengelolaan Kewirausahaan", http:/ / www.scribd.com/ doc/ 4933265/

“Revitalisasi Jiwa Kewirausahaan", http:/ / islami.com. Diakses tanggal 19 Nopember 2008.

"Penerapan Fungsi-fungsi Manajemen dalam Mengembangkan Dana", http:/ / salafiyah.org. diakses tanggal 12 A pril 2009 